\title{
An Analysis of Management Information Procedure in PT. Yamaha Tembung, Medan, Indonesia
}

\author{
Isnaniah LKS ${ }^{1}$, Patar Marbun ${ }^{2}$ \\ ${ }^{1,2}$ Faculty of Economy and Business, Medan Area University (UMA), Indonesia \\ isnaniahlaili@gmail.com
}

\begin{abstract}
In this study the authors describe the research with the title "An Analysis of Management Information Procedure in PT. Yamaha Tembung, Medan, Indonesia" at the Yamaha company. This study aims to determine whether the information management procedure system has met the elements of internal control in the company. The research method used is descriptive analysis method. The results of research conducted indicate that the overall system of information procedures applied to the company has fulfilled the elements of internal control that have been prepared well, but the elements of internal control in terms of good practice to satisfy consumers.
\end{abstract}

Keywords: Information management system; procedure; satisfaction; consumer.

\section{Introduction}

The rapid development of the era requires companies that currently have to have advantages in carrying out business processes in order to stay afloat in the business world, therefore at this time many companies are starting to utilize information systems and technology as a major component in achieving excellence in competing in business. The need for time and cost efficiency causes every business actor feels the need to apply information technology in the work environment. The management information system focuses on information for a structured decision or information that can be anticipated. It may seem simple, but actually provides information to help managers in make and decide work-related decisions that are very difficult and complex. Information management information systems play an important role in preparing strategic plans, making decisions, and controlling activities to be able to measure the level of success.

The system is a set of things or activities or elements or subsystems that work together or are connected in certain ways so as to form a unity to carry out a function to achieve a goal (Sutanta 2003. Information systems, information technology can help all type of business to improve the efficiency and effectiveness of business processes, managerial decision making, and working group cooperation, so as to strengthen the company's competitive position in a rapidly changing market (O'Brien and Marakas, 2011).

Information technology and system strategy planning is a combination of systems and information technology development activities and business strategy planning so as to produce a very profitable combination to improve the business processes and overall activities of the company. With the application of systems and information technology that is good, it will produce information that is precise and fast, so that it will help managers in determining the right business strategies and quickly to achieve the company's vision and mission by providing the information needed for consideration for decision makers. Enterprise resource planning is a cross-functional company system that integrates and automates many of the company's internal business processes, especially in the manufacturing, logistics, distribution, accounting, finance, and human resources functions of the business. 


\section{Research Methods}

As the task given to me to make an analysis of management information systems in a company. Finally, the researchers thought to take the example of a Yamaha company in Tembung, Deli Serdang Regency, Medan, Indonesia, one of my main attractions to analyze the company's management information system is the most important that this Yamaha company is the largest motorcycle company in Indonesia. in this world. Therefore the researchers really want to know how information management in this company runs so that it can become the largest automotive company in Indonesia even in the world though.

\subsection{Data Sources}

Data obtained on two types of data, namely:

a. Primary Data, i.e. the data obtained by the author through direct observation (survey) of the company that is the object of research.

b. Secondary data, namely data obtained by the author with.

Studying as well as gathering reference books about theories related to the company's management information system and by searching for many sources from the internet media, which at the end of this paper the researchers will attach a link which is the source of material for making this paper.

\subsection{Data Collection Techniques}

Data collection techniques can be done by:

a. Interview Techniques namely holding direct questions and answers and discussions directly with the company, especially with the section related to the object of research.

b. Literature Techniques that is collecting data by reading books, and reports relating to research.

c. Observation Techniques namely the method of data collection by directly observing the activities associated with sales accounting systems in the company.

After the data is obtained, the data is then processed and then analyzed. Analysis of this data is important because from this analysis, the data obtained can give meaning and meaning that is useful in solving research problems. The method used in this research is descriptive analysis by describing or describing the actual state of the object of research to find out and analyze the problems faced by the object of research then compared with standard theory.

\section{Discussion}

Good information management is a source of life for a company, because with good information will make a profit and to find out consumer interest in the products produced or sold. According to Mulyadi (2010: 163) the internal control system includes an organizational structure, methods and measures that are coordinated to maintain organizational wealth, check the accuracy and reliability of accounting data, encourage efficiency and encourage compliance with management policies. Mulyadi (2010: 163) explained the purpose of information control systems are as follows: 
a. Maintain organizational records and assets The physical wealth of a company can be stolen, blamed or destroyed by accident unless the wealth is protected with adequate control.

b. Checking the accuracy and reliability of information data.

c. Encourages efficiency. Encouraging compliance with management policies.

To achieve company goals, management establishes policies and procedures. Internal control structures are intended to provide adequate guarantees that management policies are adhered to by company employees. Mulyadi (2010: 164) also explains that the main elements of internal control are as follows:

a. An organizational structure that separates functional responsibilities explicitly.

b. A system of authority and recording procedure that provides adequate protection against wealth, debt, income and costs.

c. Healthy practices in carrying out the duties and functions of each organizational unit.

d. Employees whose quality is in accordance with their responsibilities.

In this company the information system used is the accounting model or in general the activities of this transaction are carried out by recording every transaction that is carried out.

Because all activities that occur in this company are related to the marketing of goods. So the researches have concluded to further discuss the recording management system or accounting information system which is also very related to management information systems.

The following are the functions that occur in transaction activities at this company:

a. Sales Function, this function is responsible for receiving orders from consumers, and determining whether payments are made in cash or on credit. After getting the agreement will continue on the administration. The administration section will fill in the cash sales invoice, this invoice will be processed for the handling of motor vehicle documents and records for the company submitting the invoice to the buyer for payment of the price of the goods to the cash function and bringing the goods to the shipping function. In the organizational structure of the Yamaha Dealer this sales function is carried out by the sales department.

b. Cash Function, in this cash sale transaction, this function is responsible for receiving cash from the buyer. In the organizational structure of the Yamaha Dealer this function is carried out by the Cashier.

c. Accounting Function, in transactions from cash sales, this function is responsible for recording sales and cash receipts and making reports on motorcycle unit sales. In the Yamaha Dealer organizational structure this function is in the administration section. The records are made using a manual system.

\subsection{Authority System or Procedure}

The procedure network that forms the cash sales accounting system is as follows. a. Sales Order Procedure.

This procedure involves the sales function performed by the sales department. The steps are as follows:

- Receive orders from buyers.

- Explain the product and determine the payment made whether cash payment or credit payment. 
- Carrying out the tax and STNK explanation process and power of attorney accompanied by a variety of supporting data including complete data on the buyer and controlling the motor vehicle documents with the validation of the leader. In this process it is possible for the motor vehicle control whether the naming other than the buyer.

- Provide an explanation of the vehicle service book.

- Say thank you and invite the buyer to wait for the goods in the physical checking process.

- And surrender the vehicle or motorcycle.

b. Cash Receipt Procedure

This procedure involves the cash function in receiving payment of the price of goods from the buyer carried out by the cashier with the following steps:

- After carrying out the process of recording customer or buyer data, the cash function in this case involves the cashier making proof of payment in cash in duplicate 3 and the validation process from the leadership, if the buyer makes cash payments then proof of payment in cash 1 will be given as a sign accept payment to the customer or buyer.

- Receiving money from consumers. Procedure for Submitting Goods This procedure is carried out by the garage (PDI MAN), and the steps are as follows:

1) After the motor is chosen, the workshop will do a physical check and so on for the purpose of the vehicle.

2) Delivering the goods or motorbike to the consumer or buyer.

c. Procedure for Recording Cash Revenue and Sales In this procedure involves an accounting function performed by the administration. With the evidence that has been made, it is recorded manually.

- Take the evidence used.

- Record data.

- Filing the evidence that has been made.

d. Cash Deposit Procedures to Banks

In this procedure carried out by the administration. The deposit procedure is carried out the following day, with the following steps:

- Take money from the cashier.

- Calculate cash and make a deposit slip to the bank.

- Deposit money to the bank.

- Filing proof of deposit from the bank.

While the documents and records related to the cash sales accounting system are as follows:

- Proof of payment in duplicate cash 3.

- Proof of bank deposit.

- STNK after 3 months from the purchase process.

- BPKB after 6 months from the purchase process.

- Copy of consumer or buyer ID card.

\subsection{The Functions Related to the Sales Information System}

a. Sales information function 
For the sales information function, the credit sales accounting system is the same as the cash sales accounting system, which is carried out by the sales department.

b. Cash Function

In this credit sale transaction, this function is responsible for receiving cash from the buyer. In the organizational structure of the Yamaha Dealer this function is carried out by the Cashier.

c. Credit Information Function

This function is under the financial function in which credit sales transactions are responsible for examining the customer's credit status and providing credit to customers. In this case the Yamaha Dealer is carried out by the billing department, the surveyor.

d. Billing Information Function

The function is responsible for making and sending proof of credit sales installments to customers. In this case carried out by the billing or surveyor.

The cash receipt information procedure involves the cash function in receiving credit sales payments in the form of a cash advance payment and the first month installments, carried out by the cashier. The stages are as follows:

- Making proof of sales payment in duplicate credit 3 with the validity process from the leadership, sheet 1 is submitted to the consumer as proof of payment, sheets 2 and 3 are submitted to the center but before the recording process will be done first.

- Receive money from consumers or buyers.

- Say thank you and invite consumers to wait for the goods in the checking process.

\subsection{Credit Approval Procedure}

In this procedure, the sales function requests approval of credit sales for consumers from the credit function, in this case the surveyor carries out the following steps:

- Request complete data on consumers in the form of a photocopy of a Identity Card husband and wife, family card, salary slips or electricity bills.

- Conduct a review or survey of the home of the consumer or buyer.

- Lift credit.

- Give up the motorbike to the consumer or buyer.

a. Procedure for Delivery of Goods

This procedure is carried out by the garage (PDI MAN), and the steps are as follows:

- After the motor is chosen, the workshop will do a physical check and so on for the purpose of the vehicle.

- Delivering the goods or motorbike to the consumer or buyer.

b. Billing Procedure

In this procedure, the billing or credit function performed by the surveyor, billing consumers for installments per month.

c. Procedure for Record of Receivables

In this procedure, the accounting function is carried out by the administration. With the evidence that has been made, a manual system is recorded.

- Take the evidence used.

- Record data.

- Filing the evidence that has been made. 
d. Procedure for Depositing Cash to Banks in this procedure is carried out by the administration for depositing advance payments. The deposit procedure is carried out the following day, with the following steps:

- Take money from the cashier.

- Calculate cash and make a deposit slip to the bank.

- Deposit money to the bank.

- Filing proof of deposit from the bank. For documents and records related to the credit sales accounting system are as follows:

1) Proof of advance payment on double credit 3.

2) Agreement letter.

3) Proof of bank deposit.

4) STNK after 3 months from the purchase process.

5) BPKB after the installments are paid in full.

6) Photocopy of Identity Card, Family Card, salary slip or electricity account of the consumer or buyer.

Healthy practice is an important key in achieving the goals of a company organization, employee performance will have an impact on the company. The biggest losses were experienced by several companies, one of which was a result of poor internal control. Based on data obtained from the results of research on

\subsection{Yamaha Dealers That in the Implementation of Company Activities Can Be Seen the Existence of Elements of Healthy Practices.}

a. The use of forms is numbered printed, the use of which must be accounted for by the competent authorities.

b. Scrutiny checks, the company never carries out a sudden inspection, because checks are carried out every day only carried out on the accounting function.

c. Every transaction is not carried out by one person or one organizational function without interference from other people or other organizational functions, because each organizational function has been separated and carrying out their respective duties.

The amount of cash received from the sale is not deposited to the bank on the same day as the sales transaction. Quality Employees Employees who work in accordance with their respective fields of expertise and are expected to have the nature of honesty, discipline and take full responsibility for the tasks assigned. through advertising and by carrying out several stages of selection for prospective employees based on the requirements demanded by their work. For example, for sales, cashiers and surveyors a minimum of high school graduates are equal and all majors, while for the administration department is preferred accounting department. And in an effort to improve the quality of human resources, the company held a work tranning for 3 months, this was done to see the work ability of the prospective employee.

\subsection{Evaluation of Cash Sales Accounting Systems at Yamaha Dealers}

a. Evaluation of Related Functions where the cash sales system at Yamaha Dealers already meets the elements of internal control, because there is a separation of functional responsibilities and the relationship between functions has been established by the 
company. accounting functions carried out by the administration. Each function has carried out its duties properly in the cash sales accounting system.

b. Evaluation of the Documents Used where the documents used by Yamaha Dealers have fulfilled the elements of internal control, because the proof of cash payment is numbered in print. And in the proof of payment the cash is made in duplicate, sheet 1 is handed over to the consumer as a buyer, sheet 2 is used as a Yamaha dealer archive and sheet 3 is submitted to the center.

c. Evaluation of Accounting Records Used Accounting records used by Yamaha Dealers in the cash sales accounting system have not met the elements of internal control, because in their records Yamaha Dealers still use the Manual system. So that the possibility of errors can occur in the journalizing process. We recommend that you record accounting using an accounting program, the company will automatically have a standard account account code provided by the accounting program.

d. Evaluation of the Network of Procedures that Make up the System where the network of procedures that make up the system at Yamaha Dealers in the cash sales accounting system already meets the elements of internal control. This system can run efficiently and effectively for the company's operational activities.

e. Evaluation of Healthy Practices where healthy practices adopted by Yamaha Dealers have not been good enough to meet the elements of internal control. Every transaction is not carried out by one person or one organizational function without interference from other people or other organizational functions. However, the company never carries out a sudden inspection, because checks are carried out every day and carried out on the accounting function, and the amount of cash received from the sale is not paid to the bank on the same day as the sales transaction.

f. Evaluation of Quality Employees where Yamaha dealers have done several things in order to improve the quality of employees where the company has taken steps such as hiring employees through advertisements and by conducting several selection stages for prospective employees based on the requirements demanded by their jobs.

g. Evaluation of the Credit Sales Accounting System at Yamaha Dealers where evaluation of Related Functions where the credit sales system at Yamaha Dealers already fulfills the elements of internal control, because there is a separation of functional responsibilities and the relationship between functions has been established by the company. The existing functions have been separated between the sales functions carried out by sales, the cash receipt functions carried out by the cashier, accounting functions carried out by the administration as well as credit or billing functions carried out by surveyors. Each function has performed its duties properly in the credit sales accounting system at Yamaha Dealers.

h. Evaluation of the Documents Used where the documents used by Yamaha Dealers have not been good in fulfilling the elements of internal control, because the proof of advance payment used is numbered in print. But in making proof of payment on credit this is not good enough because it is made in duplicate 3 , sheet 1 for consumers or buyers, sheets 2 and 3 are submitted to the center. It is better if the proof of credit payment is made in duplicate, sheet 1 is submitted to the consumer, sheet 2 is for Yamaha Dealers or administration and as an archive, sheet 3 is for surveyor as evidence at the time of installment payment or collection of receivables and sheet 4 is sent to the center.

i. Evaluation of Accounting Records Used where the accounting records used by Yamaha Dealers in the credit sales accounting system have not yet met the elements of internal 
control, because in their records Yamaha Dealers still use manual systems. So that the possibility of errors can occur in the journalizing process. We recommend that you record accounting using an accounting program, the company will automatically have a standard account account code provided by the accounting program.

j. Evaluation of the Network of Procedures that Make up the System where the network of procedures that make up the system at Yamaha Dealers in the credit sales accounting system already meets the elements of internal control. This system can run efficiently and effectively for the company's operational activities.

k. Evaluation of Healthy Practices where Healthy practices adopted by Yamaha Dealers have not been good enough to meet the elements of internal control. Every transaction is not carried out by one person or one organizational function without interference from other people or other organizational functions. However, the company never carries out a sudden inspection, because checks are carried out every day only on the accounting function, and the amount of cash received from sales is not paid to the bank on the same day as the sales transaction.

1. Evaluation of Quality Employees where Yamaha dealers have done several things in order to improve the quality of employees where the company has taken steps such as hiring employees through advertisements and by conducting several selection stages for prospective employees based on the requirements demanded by their jobs.

\subsection{Table of Internal Control Elements of Accounting Systems Cash sales No Internal Control Element Appropriate No.}

a Organizational structure

- The sales function must be separate from the cash function.

- The cash function must be separate from the accounting function.

- Sales transactions are not carried out by the sales function, cash function, accounting function.

b. Authority Systems and Procedures

- Receiving orders from consumers is authorized by the sales function by requesting purchase conditions.

- Cash receipts are authorized by the cash function by putting a stamp on the proof of payment in cash.

- For evidence of cash sales authorization by the accounting function to be kept as an archive.

c. Healthy Practices

- Proof of payment of serial numbers is printed and its use is accounted for by the cash function.

- Sudden inspection.

- Each transaction may not be carried out by one person or one organizational function.

- Accounting records using the accounting program Table of Internal Control Elements Credit Sales Accounting System

- The amount of cash received from the cash sale is deposited to the bank on the same day as the cash sale transaction.

d. Quality employees where selection of prospective employees based on the requirements demanded by their work. 


\subsection{No Internal Control Element Appropriate No.}

a. Organizational Structure

- The sales function must be separate from the cash function.

- The cash function must be separate from the accounting function.

- The accounting function must be separate from the credit or billing function.

- Credit sales transactions are carried out by the sales function, cash function, accounting function and credit or billing functions.

b. Authority Systems and Procedures

- Receiving orders from consumers is authorized by the sales function by requesting purchase conditions.

- Cash receipts are authorized by the cash function for advance payments.

- For proof of credit sales authorization by the accounting function to be kept as an archive.

- The billing function performs billing only on the basis of receivables that must be collected made by the accounting function.

\section{Conclusions}

From the findings discussed previously, it can be concluded that:

- The information procedure system applied to the company meets the elements of internal control in terms of organizational structure.

- The sales information system applied to the company already fulfills the elements of internal control in terms of the authority system or procedure.

- The sales accounting system applied to the company does not meet the elements of internal control in terms of sound practices.

- The sales accounting system applied to the company has fulfilled the elements of internal control in terms of quality employees.

- Healthy Practice.

\section{References}

Arikunto, Suharsimi. (2002). Metodologi Penelitian. Penerbit PT. Rineka Cipta. Jakarta. (2004). Prosedur Penelitian: Suatu pendekatan Praktek. Bandung: Rineka Cipta. (2006). Prosedur Penelitian: "Suatu Pendekatan Praktek.Jakarta: Rineka Cipta

Davis, Gordon B. (1992). Kerangka Dasar Sistem Informasi Manajemen. Jakarta: Pustaka Binaman

Pressindo.

2002. Kerangka Dasar Sistem Informasi Manajemen PPM. Jakarta.

Guntur, Dr. Effendi M. (2010). Transformasi Manajemen Pemasaran+Membangun Citra Negara. Sagung Seto, Jakarta.

Komaruddin, dan Yooke Tjuparmah, S. Komaruddin. (2000). Kamus istilah Karya Tulis Ilmiah, Bumi Aksara. Jakarta

DeLone, W.H. and E.R.Mc Lean. (1992). "Information System Success: The Quest for the Dependent Variable" Infomation System Research 3 (March). 
Hamilton, S. dan N. L. Chervany (1981). "Evaluating Information System Effectiveness Part I: Comparing

Evaluation Approaches." MIS Quarterly.

Hasibuan, Malayu S.P (2009). Manajemen Sumber Daya Manusia. Jakarta: Bumi Aksara Jogiyanto. (2005). Model Kesuksesan Sistem Informasi. Yogyakarta: BPFE. 105 Qori Rahmitiara, 2014

Kadir, Abdul. (2003). Pengenalan Sistem Informasi. Yogyakarta: Andi

Komaruddin. (2000). DesainSistem Informasi, Andi Offset, Yogyakarta

McLeod, Raymon Jr dan George P. Schell. (2010). Sistem Informasi Manajemen. Jakarta: Indeks

M. Guntur, Effendi. (2010). Transformasi Manajemen Pemasaran. Jakarta: Sagung Seto.

Nazir, Mohammad. (2003). Metode Penelitian. Jakarta: Ghalia Indonesia

Riduwan, dan Kuncoro, E Ahmad. (2008). Cara Menggunakan dan Memakai Analisis Jalur (Path Analysis).

Cetakan Kedua Alfabeta, Bandung.

Rangkuti, Freddy. (2005). Teknik Mengukur dan Strategi Meningkatkan Kepuasan Pelanggan. Jakarta: Gramedia Pustaka Utama.

Sudjana, Prof. Dr. M.A., M.Sc. (2002). Metoda Statistika. Bandung: Tarsito. (2006). Teknik Analisis Regresi dan Korelasi. Bandung: Tarsito.

Sugiyono. (2008). Metode Penelitian Bisnis. Bandung: Alfabeta.

(2009). Metode Penelitian Kuantitatif, Kualitatif dan R\&D. Bandung : CV Alfabeta

(2010). Metode penelitian Kuantitatif Kualitatif dan R\&D, Penerbit: Alfabeta

(2012). Memahami Penelitian Kualitatif'. Bandung : ALFABETA 